\title{
PENGUIN BREEDING IN EDINBURGH
}

\author{
BY
}

\author{
T. H. GILLESPIE, F.R.S.E., F.Z.S. \\ Director of the Zoological Park, Edinburgh
}

With 2 photos

The Scottish National Zoological Park at Edinburgh has been notably successful in keeping and breeding penguins. It is happy in possessing as a friend and benefactor, $\mathrm{Mr}$ Theodore E. Salvesen, head of the firm of Christian Salvesen \& Co., Leith, to whose interest and generosity it owes the great number of penguins it has possessed. Of the seventeen known species of penguins, seven are represented in the Park; the king (Aptenodytes patagonica Miller), gentu (Pygoscelis papua Forster), ringed (Pygoscelis antarctica Forster), macaroni (Catarrhactes chrysolophus Brandt), Magellan (Spheniscus magellanicus Forster), Peruvian (Spheniscus humboldti Meyen) and black-footed (Spheniscus demersus L.). The collection has risen as high in number as 180 individuals, but at present numbers only about 70 . The first penguins received in the Park were three king penguins which arrived from South Georgia in January 1914. One of these three was fully adult and was therefore not less than two years old at the time of its arrival. I am happy to say that it is still alive. It is a female and was the mother of the first chick hatched in the Park. The other two which came at that time were in the brown nestling plumage and were probably, therefore, just about a year old when they arrived. One of these young ones, a male, was, after it had moulted, much courted by the adult, but in spite of the attention paid to it by the adult female in the years 1915 , 1916 and 1917, it showed little inclination to respond and was, I concluded, not sexually mature at that time. In 1918 the female laid an egg which was not fertile. On the Ist of September I9ig another egg was laid. This egg was incubated by the parents, both birds taking turns with the egg though the greater part of the work of incubation seemed to fall upon the male. The king penguin makes no nest, but holds its single egg on the feet and covers it with the skin and feathers of the lower part of the abdomen. There is nothing in the way of a pouch for brooding the egg and the egg is held between the two feet placed close together and the lower part of the body. The penguin is able to move about in an awkward shuffling manner with the egg held on its feet, and so firmly can it be held that the bird can even climb a rock, or fall from a rock, without losing its grip of the egg. On the 26th of October 
the egg was found to be chipped, and on the second day after that the young penguin emerged. The king penguin chick, when newly hatched, shows traces, especially on the head, of a natal coat of white down-like feathers. This disappears within two or three days and the growth begins of a brown nestling coat. This seems to suggest that the king penguin chicks were at one time clothed in a white nestling coat like that of the emperor penguin, but that either a movement to more northerly breeding grounds, or a change to a less glacial climate of the established breeding ground, induced a corresponding change in the colour of the nestling coat. The chick is, like the young of all penguins, fed on pre-digested fish which it takes from the throat of the parent bird. It has been noted that for a day or two before the egg hatches the adult bird is disinclined to feed, perhaps so that there may be a supply of fully digested food available for the very small chick when it first appears. The parent birds soon, however, begin to feed more greedily again. The food regurgitated is at first quite liquid, but in a few days quite large pieces of fish are brought back. The chick has a warbling flute-like call which it utters when it wishes to feed. The growth of the chick is fairly rapid, though not so rapid as in the case of the smaller penguins. By the time the chick was eight weeks old it had attained so large a size and was making such demands upon the parents for food that they seemed to be growing weak, so the experiment was made of giving the chick its own allowance of fish, small herring and whiting being used for the purpose. The chick took very readily to the change and was soon taking its 14 to 20 herrings a day. This enabled the parent birds to recover. condition, but one wonders how wild king penguins manage to endure the strain of finding sufficient food, not only for themselves but for the chick, as they must do, until it is about a year old. In due course this chick was reared and it went into its first moult in April 1920 , about six months after it was hatched. In the following year, I920, two pairs of king penguins laid eggs but neither egg hatched. The same thing happened the next year. More adults had been received from South Georgia and in 1922 three eggs were laid and two hatched, but each of the chicks died when it was just three days old. The year 1923 brought a similar experience. I was puzzled to understand why these chicks died so quickly and I reviewed the circumstances and compared them with those attending the hatching and rearing of the first chick. I could perceive no difference in conditions or treatment except one, that while the first successful egg had been laid and incubated in the late autumn, when the weather was bleak and wet, subsequent eggs had been laid in June and the chicks hatched in August when the weather was hot and dry. In order to compensate for this difference I arranged, in 1924, a fine spray in the penguins' enclosure which kept a portion of rock always wet. When the first egg was laid in June 1924, this spray was turned on and the incubating birds kept pretty much within its range. A second egg also was laid in 1924 and both these eggs hatched and the chicks were reared. I concluded, therefore, 
that the spray had solved the problem and since then I have a spray in each of the penguin enclosures and keep the spray going whenever the weather is hot. One of the I924 chicks is still alive although the other, and that of I9I9; are both dead. Meantime, in 1925, the male of the original pair had died and there was no fertile egg in 1926, but in the years 1927 to 1932 inclusive, a chick was hatched each year and several of them, but not all were reared. In I932, a consignment of 16 adult penguins was received from South Georgia and these

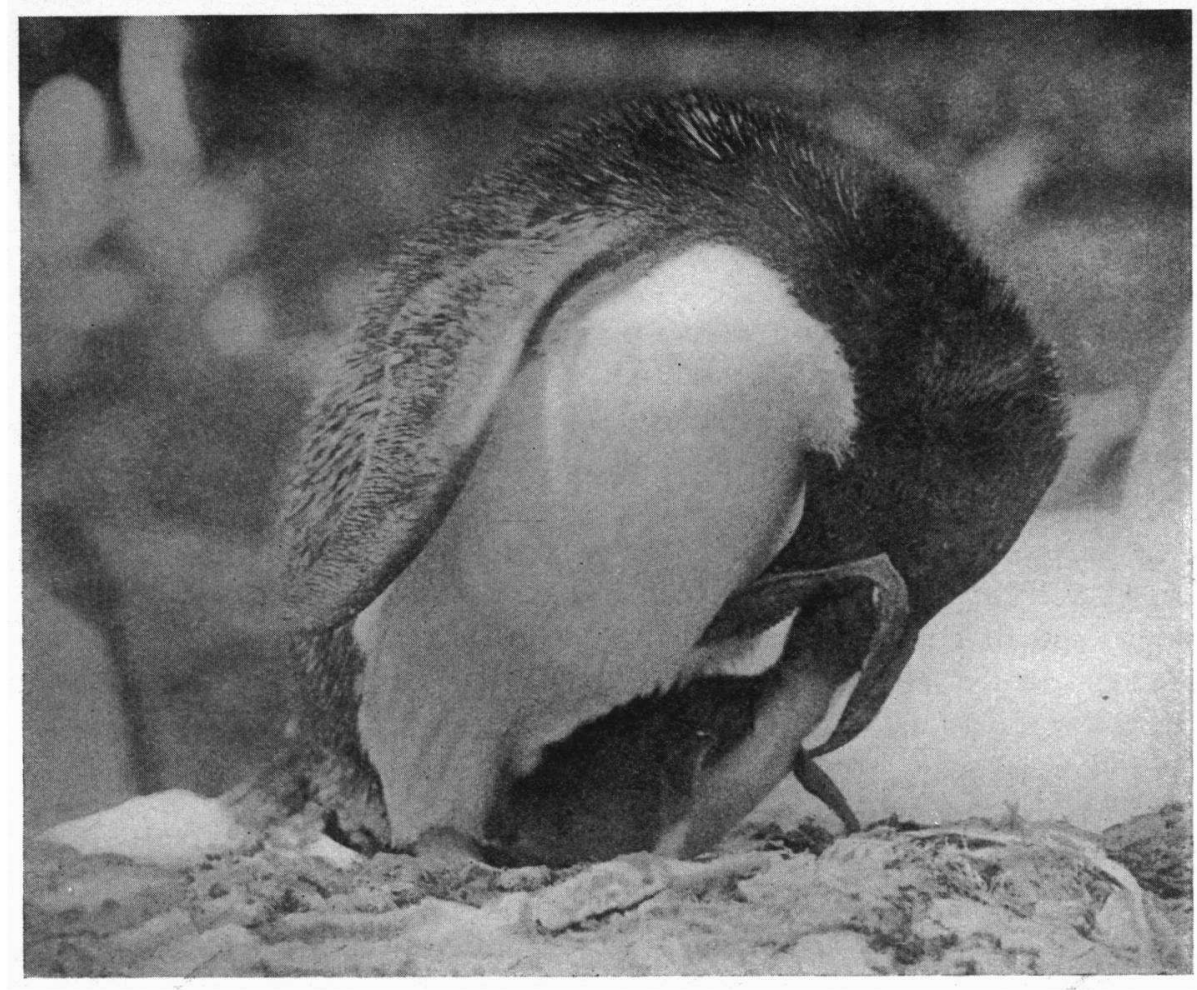

Macaroni Penguin feeding chick.

Photo Mrs T. H. GILLEsPIK

I have kept in a separate enclosure so that they form a second colony. They also have bred successfully and in all twenty two king penguin chicks have been hatched and reared in the Park. Four of them are being reared at the present time. As many as nine king penguins were incubating eggs at one time in the Park last August, but only four of the eggs hatched. So much for the king penguins.

The next breeding result we had was in 1935. In the spring of 1933 we had received a number of ringed penguins from the Antarctic and in May 1935, two pairs of them started to nest. The ringed penguins (or "chin-strap" penguins, as the Americans sometimes call them) make a nest of stones, the 
behaviour of the birds being very similar to that of the Adelie penguins as described by Dr Murray Levick in his book on Antarctic Penguins. The first step in courtship seems to be to select a small stone and lay it at the feet of the chosen lady. If she is responsive a great deal of bowing and braying (for the voice of the smaller penguins resembles nothing so much as that of a donkey) follows. The birds set about collecting a heap of pebbles on top of which a hollow is made in which the eggs are laid. Two eggs are laid. Incubation lasted for thirty five days and one egg hatched, but the chick unhappily only lived for three days and the other egg was infertile. The ringed penguins are, I consider, more difficult to keep than any other penguins we have had. Its range lies further south than that of the gentu or macaroni and it has a smaller defence against the diseases of our germ-laden atmosphere and quickly falls a victim to that mould infection which is so frequent a cause of death of penguins. Our ringed penguins were gradually dying off and though in the subsequent years and even in this present year a certain amount of nest building took place, and one or two eggs were laid, no more were hatched.

The macaroni penguins in the Park also decided to breed in 1935. Their habits of courtship and nest-building resemble those of the ringed penguin. A pile of stones is collected and the eggs are laid in the hollow top. The macaroni penguin seems to prefer a nesting site close to the water and they chose a small cluster of rocks on the very edge of the pool. The ringed penguins, on the other hand, seemed to prefer a higher position further away from the water. The first pair of macaroni penguins had two eggs, but one of them was apparently broken,-at any rate it disappeared. The remaining egg hatched in thirty eight days, but this chick also died within three days. In the following year (1936) a pair of macaroni penguins again nested and a chick was hatched and duly reared. This year (1938) also the macaroni penguins reared a chick.

In the early spring of 1937 , the colbny of gentu penguins which numbered r 8 showed signs of an inclination to breed. There seemed to be two or three pairs mated and a great deal of activity in nest building went on for some weeks. The gentu penguins preferred coarse grass and brush-wood for nesting material, but when they could not find sufficient they used small pebbles. All were active in stealing their neighbours' nesting materials when the neighbours' backs were turned and it was amusing to see how one pair would collect tufts of grass and build them into their nest, then go of $f$ to the water for a swim and immediately they had entered the water another penguin would waddle forward, seize a beakful of grass, and carry it off to another nest. Sometimes the raider was seen by the lawful owner of the nest who hurried ashore and drove off the robber. Ultimately one pair of the gentu penguins had eggs, one of which was infertile but the other hatched. The period of incubation was, as in the case of the macaroni penguin, thirty eight days. This chick was duly reared. In 1938 no fewer than seven pairs of gentu penguins 
built nests, and two eggs each were laid in five of them. No eggs appeared in the other two nests and it was suspected that these "pairs" might consist of two cock birds going through the formality of nest building. Five chicks were hatched but two of them died of mycosis when they were fully grown, but before they had moulted into adult plumage. The other three were safely reared.

The gentu penguin chick is covered, at first, in a nestling plumage of a rather dark silvery gray on the back, and white in front, and at its first moult it assumes full adult plumage, so that it is impossible to distinguish the young

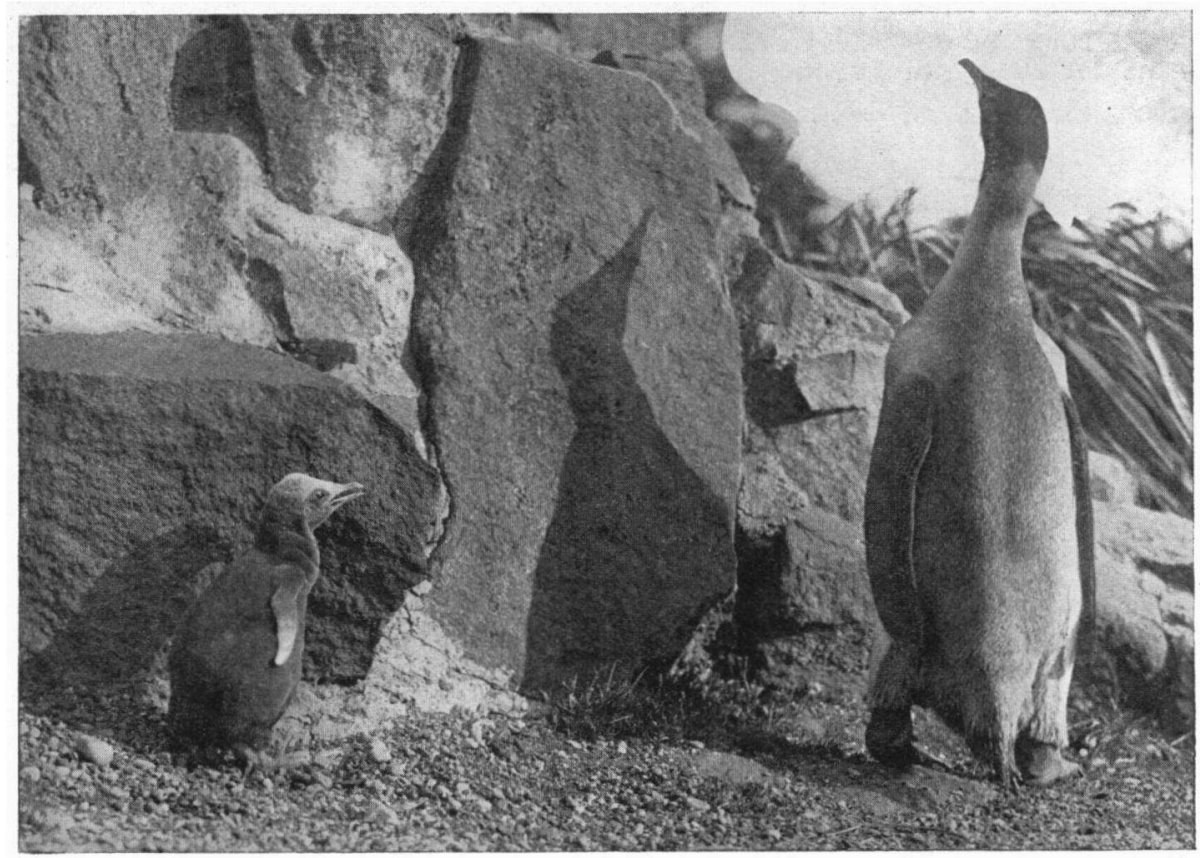

King Penguin Chick (10 days old).

Photo Mrs T. H. GricrspIE

birds from the old except by putting marks on them. The young of the macaroni penguin has a nestling coat of almost black on the back and white in front and it also moults out at its first moult into adult plumage except that the two tufts of yellow feathers, one on each side of the head, which distinguish the adult, do not appear at first: on the young, but are represented by pale streaks. In the king penguin the young bird at its first moult assumes an intermediate plumage in which the yellow patches on the side of the head are a pale shade of lemon instead of the rich orange colour of the adult, and the orange on the throat is almost entirely absent. The intermediate plumage of the young king penguin resembles in fact the adult colouring of the emperor penguin.

Another contrast between the king penguin and the smaller species which 
breed in the park, is shown in the difference in the period of juvenility. In the king penguin the period of growth from the date of hatching till the full size is attained is about 16 to 20 weeks and some months more may pass before the chick undergoes its first moult.

I have found that the first moult of the king penguin chicks always takes place about April or May irrespective of the date when it was hatched. In the gentu penguin and also in the macaroni penguin, the growth of the chick is much more rapid and the gentu chicks had moulted into adult plumage and were indistinguishable from their parents in ten weeks from the time they hatched. This difference doubtless is related to the difference in habits of the birds, for the gentu and macaroni penguins are migratory species which breed during the southern summer and leave the breeding grounds as autumn comes on, whereas the king penguin is a sedentary species and there is no seasonal compulsion to hasten the complete development of its young.

The black-footed penguins,--but who is interested in them!? They are, in spite of the fact that they are so commonplace in Zoos and breed so regularly, very interesting in their behaviour. Our black-footed penguins (which have an enclosure of their own supplied with earth banks into which the birds can burrow, and with rock caves for nesting when they prefer them) breed frequently. We find, however, that it is much more difficult to rear the chicks to full maturity. One curious thing $I$ notice is that while invariably two eggs are laid and two chicks are hatched and the parents feed both chicks for some time, after a few weeks they seem to concentrate on one chick only and drive the other one away so it would die of starvation if it were not fed by hand. The black-footed chicks moreover do not adapt themselves so readily to handfeeding as the other penguins. 